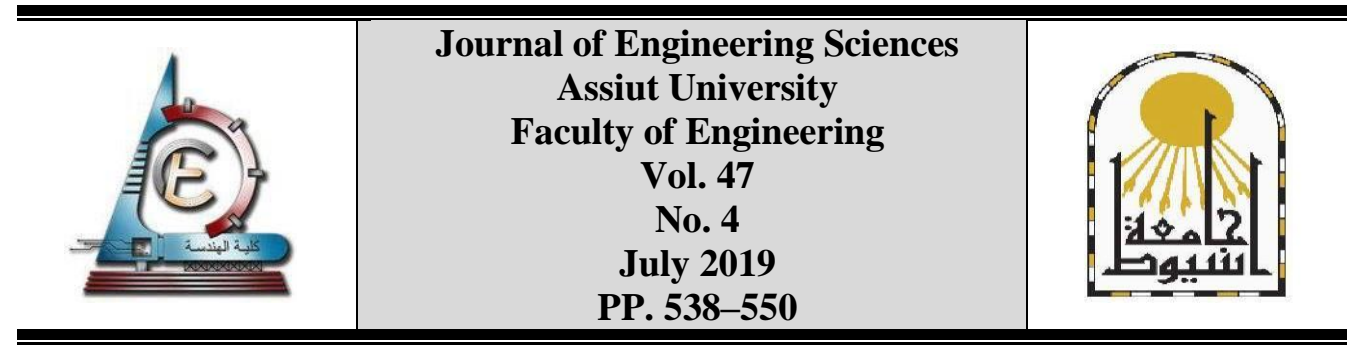

\title{
ENVIRONMENTAL ANALYSIS OF A DAY-CARE BUILDING IN EGYPT BY LIFE CYCLE ASSESSMENT TOOL
}

\section{Sara Hassan S. Abdelhalem, Nady Mustafa A. Amri, Ahmed bdelmontaleb M. Ali.}

Architectural Engineering Department, Faculty of Engineering, Assiut University, Egypt.

Received 5 March 2019; Accepted 12 March 2019

\begin{abstract}
This paper aims to measure the footprint for construction materials and construction and demolition waste (CDW) environmental impacts for a case study building in Egypt through the complete Life Cycle Assessment (LCA) of the building 'from cradle to grave'. The LCA measures eight impact categories, including carbon emissions and energy demand. Our analysis demonstrates the relative importance of life cycle stages; construction processes and materials manufacturing that make the largest contributions to the buildings' environmental impacts. The results show that the material manufacturing stage is the most critical stage because of its high contribution (about 70\%) of the total environmental impacts. On the other hand the disposal stage contributes (about $-10 \%$ ). The results can help engineers and construction industry stakeholders in Egypt to use more sustainable construction materials and change their CDW management practice.
\end{abstract}

\section{Introduction}

Life Cycle Assessment (LCA) is a universally recognised assessment tool which evaluates the environmental impacts for a product or an activity for all the stages of the product starting from raw materials extracting from the earth, energy consumption to the product disposal [1]. LCA assess the environmental impacts for the whole building life cycle by compiling an inventory of building raw resources (raw material extraction stage, transportation these materials to manufacturing sites), energy consumption (material manufacturing, materials transportation to construction site, on-site construction stage, and use/maintenance stage) to the building demolition and waste disposal, interpreting the results of the inventory analysis and impact assessment. Fig. 1 shows the whole life cycle of building products.

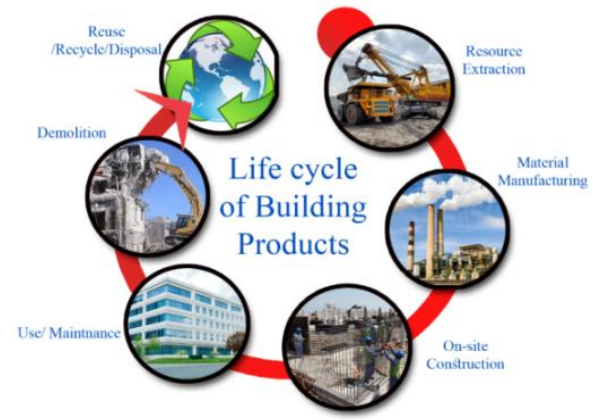

Fig. 1. The life cycle of building [2] 
539

Sara Hassan S. Abdelhalem et al., Environmental analysis of a day-care building in Egypt .......

\subsection{Resource extraction stage}

The extraction of raw resources like iron, aggregates, wood, coal and gypsum is the first stage of most buildings' life cycle. This stage includes the energy used in the transportation of these resources to manufacturing site [2]

\subsection{Manufacturing stage}

Including the processes of production of materials and components used in the construction. This stage consumes energy and raw resources.

\subsection{On-site construction}

This is an important life cycle stage, including building product transportation, waste generation, and the energy used for machines like cranes and mixers, the on-site construction stage includes on site processes and materials transportation on site [3].

\subsection{Use /Maintenance stage}

The use /maintenance stage includes energy use, and the water used during its operation. It also takes into account the material replacing which happening in the building during its operation, which introduces new products or systems.

\subsection{End of life and disposal stage}

Demolition represents the end of a building's life cycle. This stage includes energy consumed in the building demolition and transportation of CDW to landfill or waste sorting site. It includes reusing and recycling for CDW as well.

\section{Literature review}

Table 1 shows the findings of some of the most recent LCA and economic studies implemented CDW management. LCA has been widely used to estimate and compare the environmental performances and impacts of different waste management practices. Regarding CDW management, some recent LCA studies focused on the comparison among the different end of life scenarios [1]. 


\section{Table 1.}

Environmental and Economic analysis on CDW: literature review.

\begin{tabular}{|c|c|c|c|c|}
\hline & Methodology & Focus & Goal & Findings \\
\hline \multicolumn{5}{|c|}{ Environmental Analysis [1]. } \\
\hline $\begin{array}{l}\text { Ortiz et al. } \\
(2010)\end{array}$ & LCA & $\begin{array}{l}\text { CDW } \\
\text { Management }\end{array}$ & $\begin{array}{l}\text { Comparison of different } \\
\text { CDW end of life scenarios } \\
\text { (land filling vs Recycling) }\end{array}$ & $\begin{array}{l}\text { Recycling has lower overall } \\
\text { environmentalimpacts } \\
\text { compared to landfilling }\end{array}$ \\
\hline $\begin{array}{l}\text { Hossain } \\
\text { et al. } \\
(2016 a)\end{array}$ & LCA & Aggregates & $\begin{array}{l}\text { Comparison of aggregates } \\
\text { produced from CDW and } \\
\text { Glass waste }\end{array}$ & $\begin{array}{l}50 \% \text { of the environmental } \\
\text { impacts can be reduced when } \\
\text { producing aggregates from } \\
\text { CDW instead that from natural } \\
\text { resources }\end{array}$ \\
\hline $\begin{array}{l}\text { Rosado et al. } \\
\text { (2017) }\end{array}$ & LCA & Aggregates & $\begin{array}{l}\text { Comparison of recycled } \\
\text { CDW vs natural aggregates } \\
\text { produced for road } \\
\text { construction in Brazil }\end{array}$ & $\begin{array}{l}\text { CDW recycled aggregate is a } \\
\text { better than natural aggregates } \\
\text { for all the environmental impact } \\
\text { categories if the distance of the } \\
\text { recycling facility from the } \\
\text { consumer is within a given } \\
\text { range }\end{array}$ \\
\hline $\begin{array}{l}\text { Hossain } \\
\text { et al. } \\
(2016 \mathrm{~b})\end{array}$ & LCA & Concrete & $\begin{array}{l}\text { Comparison between blocks } \\
\text { manufactured with raw } \\
\text { materials and eco-blocks } \\
\text { manufactures with recycled } \\
\text { CDW }\end{array}$ & $\begin{array}{l}\text { Eco-blocks have significant } \\
\text { lower impacts in terms of } \\
\text { energy consumption, global } \\
\text { warming potential, Acidification } \\
\text { potential and respiratory } \\
\text { inorganic potential. }\end{array}$ \\
\hline \multicolumn{5}{|c|}{ Economic analysis } \\
\hline $\begin{array}{l}\text { Wang et al. } \\
(2018)\end{array}$ & LCA & $\begin{array}{l}\text { CDW } \\
\text { Management }\end{array}$ & $\begin{array}{l}\text { Optimize CDW fee by } \\
\text { considering the } \\
\text { environmental impacts of } \\
\text { CDW and society's } \\
\text { willingness to pay }\end{array}$ & $\begin{array}{l}\text { CDW fee is an effective method } \\
\text { for improving CDWM and its } \\
\text { negative environmentalimpacts. }\end{array}$ \\
\hline \multicolumn{5}{|c|}{ Combined environmental and economic analysis } \\
\hline $\begin{array}{l}\text { Anderia et al. } \\
(2018)\end{array}$ & $\mathrm{LCA}+\mathrm{LCC}$ & $\begin{array}{l}\text { CDW down } \\
\text { cycling vs. } \\
\text { recycling }\end{array}$ & $\begin{array}{l}\text { Analyse the environmental } \\
\text { and economic drivers in } \\
\text { CDW end of life scenario }\end{array}$ & $\begin{array}{l}\text { LCA \& LCC results indicate } \\
\text { that the landfilling has the } \\
\text { highest environmental impacts } \\
\text { and economic cost. }\end{array}$ \\
\hline $\begin{array}{l}\text { Coelho and } \\
\text { De Brito } \\
(2013 \mathrm{c})\end{array}$ & $\begin{array}{l}\text { LCA + Cost } \\
\text { Benefits } \\
\text { Analysis }\end{array}$ & $\begin{array}{l}\text { CDW } \\
\text { recycling } \\
\text { plant }\end{array}$ & $\begin{array}{l}\text { Combining technological, } \\
\text { economic and environmental } \\
\text { aspects of operating CDW } \\
\text { recycling facilities }\end{array}$ & $\begin{array}{l}\text { Environmental viability of } \\
\mathrm{CDW} \text { recycling installation and } \\
\mathrm{CO} 2 \text {-eq emissions reduction. }\end{array}$ \\
\hline $\begin{array}{l}\text { Braga et al. } \\
(2017)\end{array}$ & $\begin{array}{l}\text { LCA + Costs } \\
\text { Analysis }\end{array}$ & Concrete & $\begin{array}{l}\begin{array}{l}\text { Analysis of the most } \\
\text { sustainable } \\
\text { composition }\end{array} \\
\text { concrete }\end{array}$ & $\begin{array}{l}\text { Greater environmental impacts } \\
\text { are not necessarily associated } \\
\text { with higher costs. }\end{array}$ \\
\hline
\end{tabular}

The work mentioned in the literature emphasizes that using CDW as a building materials has many environmental and economic benefits, it contributes in reducing air, land, and water emissions which released from waste incineration, or landfill dumping. In addition, it saves raw sources and the energy used in materials extraction and manufacturing. In this study, the environmental impacts is measured for a case study building in Egypt during its life cycle. From material manufacturing stage to the disposal stage with focusing on the end of life stage to provide an approach for reconsider the construction and demolition waste management practice in Egypt.

\section{Methodology}

The frame work of the environmental impacts for a Day-care building life-cycle in New Assiut City, Egypt. By Athena Impact Estimator for buildings (Athena Sustainable Material Institute) with focusing on the end of life stage. 


\subsection{Case study description}

The case study is a day care building located in New Assiut city (NAC), Egypt. The building is a single level of about $568 \mathrm{~m}^{2}$, with $5 \mathrm{~m}$ height, sees Fig. 2. The entire structure of the building is made of reinforced concrete. The building including 5 class rooms, multipurpose hall, 2 office rooms, court, kitchen, storage and 8 wash rooms.

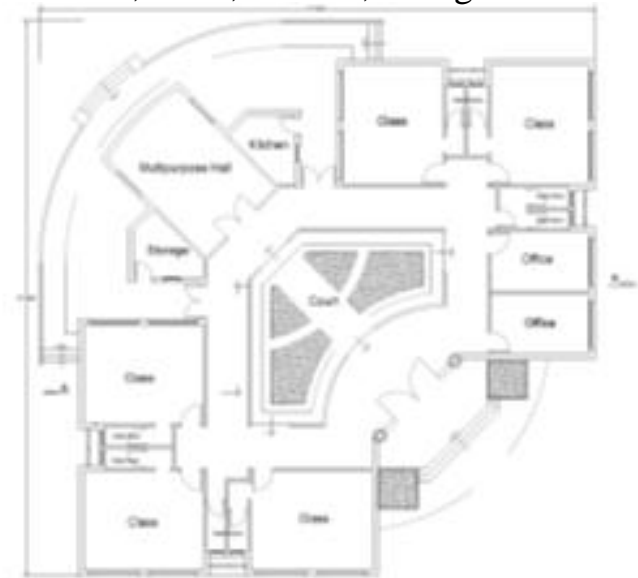

(a) The building floor plan

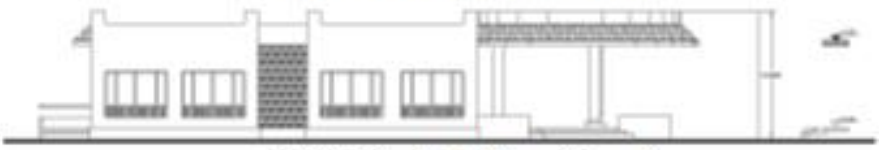

(b) Main Building Façade

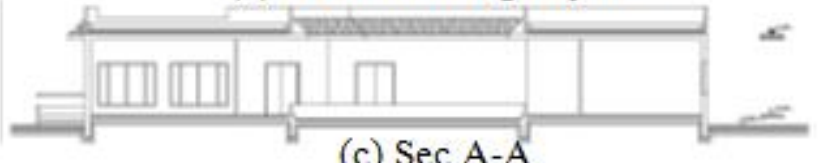

(c) Sec A-A

Fig. 2. Day care building in NAC, Egypt.

\subsection{Steps of LCA process}

ISO 14040 considers the principles and framework for an LCA, while ISO 14044 specifies the requirements and guidelines for carrying out an LCA study. An LCA study includes four main steps:

Step 1: Defining the goal and scope of the study.

Step 2: Making a model of the product life cycle with all the environmental inputs and outputs. This data collection effort is usually referred to as life cycle inventory (LCI). Step 3: Understanding the environmental relevance of all the inputs and outputs. This refers to as life cycle impact assessment (LCIA).

Step 4: The interpretation of the study [4]. Fig. 3 shows the steps of LCA according to the ISO standards. 


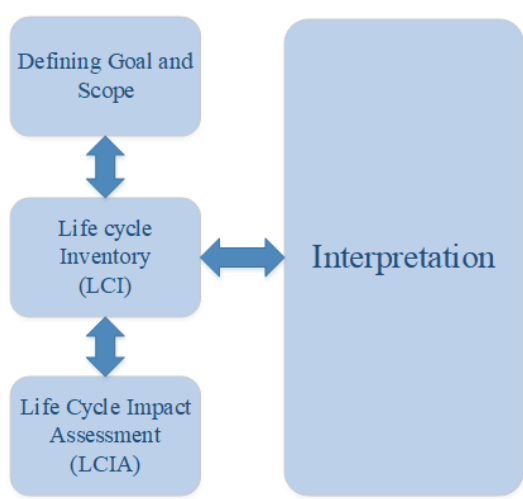

Fig. 3. LCA phases according to ISO 14040 [5]

\subsubsection{Defining goal and scope}

The Main aim of this study is to measure the environmental impacts for a Day care building as a case study in Egypt throughout its entire life cycle stages by Athena Impact Estimator for buildings as an LCA tool.

- System Boundaries: Complete LCA divided into 3 phases: preoperational (raw material extraction, material manufacturing and construction), operational (use and maintenance) and post-operational (end-of-life).

- Functional unit: The functional unit is the usable floor space $\left(\mathrm{m}^{2}\right)$ for the studied building. The building expectancy period is 60 years.

\subsubsection{Life cycle inventory (LCI)}

Inventory analysis is an essential part which uses LCA to recognize the environmental impacts for the construction materials from manufacturing, Construction, transportation to the end of life. In addition to resources and energy consumption [14]. From the literature review Egypt suffered from shortage of life cycle database, thus, the authors collected all the material quantities and specifications in Table 2 and any missing data will be taken from literature review and Athena Impact Estimator for buildings database [6].

- Pre-operational phase: This phase included the total quantity of the construction materials and the consumption of water and electric energy during the construction stage. In addition, the construction waste, the transportation of material from raw resources to manufacturing sites then to the construction sites and the waste transportation to the landfill.

- Operational phase: In this phase, the water, electric energy, and natural gas consumption used in lighting, air conditioners and heating and the construction materials required for building maintenance were considered. As in the construction, solid waste generated by the replacement of components in the maintenance process, the transportation of these materials and the generated waste were included.

- Post-operational phase: In this phase, the data for building demolition was calculated from construction industry stakeholders in Egypt. All the waste is sent to landfill without any processing. 
Sara Hassan S. Abdelhalem et al., Environmental analysis of a day-care building in Egypt ......

Table 2.

The total construction material quantities and specifications for the case study

\begin{tabular}{|c|c|c|c|c|}
\hline Building Materials & Unit & Total Quantity & Mass Value & Mass Unit \\
\hline Concrete & $\mathrm{M}^{2}$ & 0.7476 & 1.7414 & Tonnes \\
\hline Wood & $\mathrm{M}^{3}$ & 48.4800 & 23.0498 & Tonnes \\
\hline Paintings & $\mathrm{M}^{2}(25 \mathrm{~mm})$ & $2,761.5000$ & 1.9883 & Tonnes \\
\hline Joint Compound & Tonnes & 0.0056 & 0.0056 & Tonnes \\
\hline Mortar & $\mathrm{M}^{3}$ & 345.0000 & 651.3600 & Tonnes \\
\hline Nails & Tonnes & 0.0001 & 0.0001 & Tonnes \\
\hline Paper Tape & Tonnes & 0.0001 & 0.0001 & Tonnes \\
\hline Precast Concrete & $\mathrm{M}^{3}$ & $1,638.0000$ & $4,006.5480$ & Tonnes \\
\hline Rebar & Tonnes & 0.0505 & 0.0505 & Tonnes \\
\hline Gypsum Board & $\mathrm{M}^{3}$ & 5.6254 & 0.0507 & Tonnes \\
\hline Steel & Tonnes & 1.6968 & 1.6968 & Tonnes \\
\hline Water & $\mathrm{L}$ & $62,791.2000$ & 47.0934 & Tonnes \\
\hline Total mass value & & 0 & $4,733.5846$ & Tonnes \\
\hline \multirow{2}{*}{$\begin{array}{l}\text { Energy Consumption during } \\
\text { Material Manufacturing stage }\end{array}$} & Unit & Manufacturing & Transportation & Total \\
\hline & MJ & $3.11 \mathrm{E}+07$ & $6.52 \mathrm{E}+03$ & $3.11 \mathrm{E}+07$ \\
\hline \multirow{2}{*}{$\begin{array}{l}\text { Energy Consumption during } \\
\text { Construction stage }\end{array}$} & Unit & Construction & Transportation & Total \\
\hline & MJ & $2.11 \mathrm{E}+06$ & $1.80 \mathrm{E}+06$ & $3.91 \mathrm{E}+06$ \\
\hline \multicolumn{5}{|c|}{ Energy and water consumption during Use/ Maintenance stage (6). } \\
\hline \multicolumn{3}{|l|}{ Electricity consumption monthly } & \multicolumn{2}{|c|}{$492 \mathrm{KW}$} \\
\hline \multicolumn{3}{|l|}{ Natural Gas consumption monthly } & \multicolumn{2}{|c|}{$16 \mathrm{M}^{3}$} \\
\hline \multicolumn{3}{|l|}{ Water consumption monthly } & \multicolumn{2}{|c|}{$100 \mathrm{M}^{3}$} \\
\hline
\end{tabular}

\subsubsection{Life cycle of construction and demolition waste (CDW)}

Construction waste in NAC transported to landfill. The environmental impacts for construction waste should be taken in the account of the whole life-cycle impacts. The lifecycle of construction waste includes: material manufacturing stage, transportation stage, on-site construction stage, and end of life stage.

- Material manufacturing stage: This stage refers to the production of building materials in factory. For example, concrete is made by mixing aggregates, sand, water, and cement. This process consumes raw materials, energy and release emissions [3].

- Transportation stage: This stage indicates transporting building materials from factory to construction site.

- On-site construction stage: This stage called waste generation stage. In this stage building materials transfer to construction waste for many reasons: 1) Design changes during construction stage, 2) Design and construction detail error, 3) Materials damage during transportation, 4) Difficulties accessing vehicles that reach construction sites. 5) Inadequate protection during unloading, 6) Improper methods of unloading, 7) Lack of on-site waste management plans, 8) Insufficient planning for required quantities, 9) 
Material damage due to material handling. Therefore, the construction stage is a very important part of life-cycle of construction waste [7], [8], [9], [13].

- End of life stage: This stage causes many environmental impacts, because the construction waste is sent to the landfill without reusing or recycling. This stage releasing lots of land emissions [10].

Table 3 shows the land emissions that released during the end of life stage according to Athena Impact Estimator for buildings. Solid waste releases the biggest amount of emissions during demolition, disposal and waste processing. In addition to the released emission during its transportation to landfill.

Table 3.

The total emissions to land during End of life stage.

\begin{tabular}{|l|c|r|r|r|}
\hline Emissions to land & Unit & $\begin{array}{c}\text { De-construction, } \\
\text { Demolition, } \\
\text { Disposal \& } \\
\text { Waste } \\
\text { Processing }\end{array}$ & Transport & Total \\
\hline Other Solid Waste & $\mathrm{Kg}$ & $3.46 \mathrm{E}+02$ & $1.71 \mathrm{E}+02$ & $\mathbf{5 . 1 7 E}+\mathbf{0 2}$ \\
\hline Solid Waste to Landfill & $\mathrm{Kg}$ & $1.85 \mathrm{E}+06$ & $0.00 \mathrm{E}+00$ & $\mathbf{1 . 8 5 E}+\mathbf{0 6}$ \\
\hline
\end{tabular}

Environmental impacts mainly include energy consumption, resource consumption and greenhouse gas emissions, which include greenhouse gas, acidification, etc. The environmental impact indicator for construction waste has been identified in [1], as shown in Table 4.

Table 4.

Environmental impact indicator of construction waste [1].

\begin{tabular}{|c|c|c|c|}
\hline Impacts & Indicators & unit & Impact source \\
\hline Greenhouse-gas & $\mathrm{CO}_{2}, \mathrm{CH}_{4}$ & Kgeq.c & Energy consumption \\
\hline Acidification & $\mathrm{SO}_{2}, \mathrm{NH}_{3}, \mathrm{NOx}$ & Kgeq & $\begin{array}{l}\text { Building material manufacture and waste } \\
\text { treatment }\end{array}$ \\
\hline Eutrophication & $\mathrm{NH}_{3}-\mathrm{N}, \mathrm{TP}, \mathrm{COD}$ & Kgeq. $\mathrm{NO}_{3}$ & $\begin{array}{l}\text { Building material manufacture and waste } \\
\text { treatment }\end{array}$ \\
\hline Dust & Dust & $\mathrm{Kg}$ & $\begin{array}{l}\text { Building material manufacture and waste } \\
\text { treatment }\end{array}$ \\
\hline $\begin{array}{l}\text { Photochemical } \\
\text { pollution }\end{array}$ & Co (Vehicle) & $\mathrm{Kg}$ & Transportation \\
\hline Land occupation & Land & $\mathrm{Kg}$ & $\begin{array}{l}\text { Building material manufacture and waste } \\
\text { landfill }\end{array}$ \\
\hline Water consumption & Water & $\mathrm{Kg}$ & Life-cycle \\
\hline Energy consumption & Standard coal & Kgeq.SCE & Energy consumption \\
\hline $\begin{array}{l}\text { Raw material } \\
\text { consumption }\end{array}$ & $\begin{array}{l}\text { Iron, copper, Zinc, } \\
\text { manganese, etc }\end{array}$ & $\mathrm{Kg}$ & Building material manufacture \\
\hline
\end{tabular}

This study identified the energy consumption at the end of life stage. Fig. 4 shows the demolition and disposal stage consumes Gasoline and Non-Hydro renewable. The end of life stage (Demolition \& disposal, and waste transportation) consumes 11 sources of energy i.e., Hydro, coal, Diesel, Heavy fuel oil, LPG, Natural Gas, Nuclear, Renewable energy, Primary energy, Non-renewable energy, and Fossil Fuel. Fig. 5 shows the environmental impacts for the end of life stage. Then the most influencing impacts are shown in Table 5, which shows greenhouse gases emissions, acidification and resource consumption. 


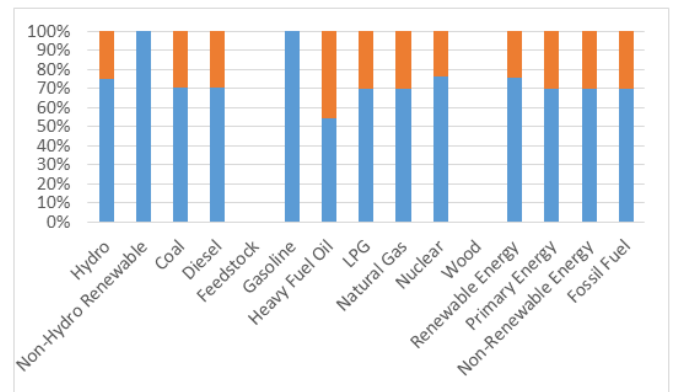

Fig. 4. Energy consumption during the end of life stage

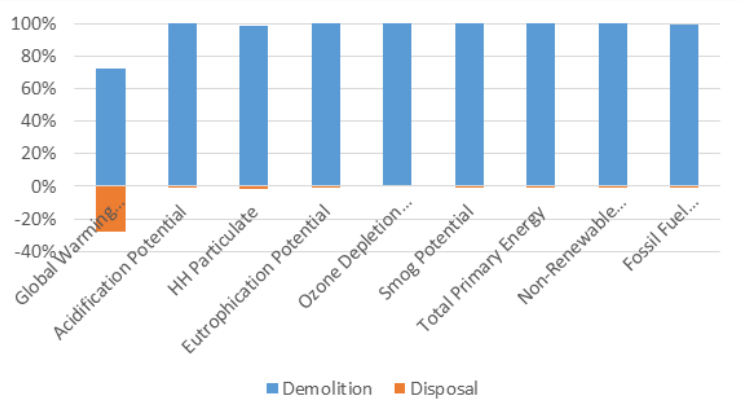

Fig. 5. The environmental impacts for the demolition and disposal

Table 5.

Emissions to air and resource consumption during end of life stage

\begin{tabular}{|c|c|c|c|c|c|}
\hline Environmental Impact & Emission & Unit & $\begin{array}{c}\text { Demolition } \\
\text { and } \\
\text { Disposal }\end{array}$ & Transport & Total \\
\hline \multirow[t]{6}{*}{ Greenhouse gas } & $\begin{array}{l}\text { Carbon } \\
\text { dioxide, } \\
\text { biogenic }\end{array}$ & $\mathrm{kg}$ & $2.86 \mathrm{E}-02$ & $0.00 \mathrm{E}+00$ & $2.86 \mathrm{E}-02$ \\
\hline & $\begin{array}{l}\text { Carbon } \\
\text { dioxide, fossil }\end{array}$ & $\mathrm{kg}$ & $3.30 \mathrm{E}+04$ & $1.46 \mathrm{E}+04$ & $4.76 \mathrm{E}+04$ \\
\hline & $\begin{array}{l}\text { Carbon } \\
\text { dioxide, land } \\
\text { transformation }\end{array}$ & g & $1.43 \mathrm{E}+03$ & $2.17 \mathrm{E}+03$ & $3.60 \mathrm{E}+03$ \\
\hline & $\begin{array}{l}\text { Carbon } \\
\text { disulfide }\end{array}$ & g & 2.39E-09 & $0.00 \mathrm{E}+00$ & $2.39 \mathrm{E}-09$ \\
\hline & $\begin{array}{l}\text { Carbon } \\
\text { monoxide }\end{array}$ & g & $1.72 \mathrm{E}-02$ & $2.11 \mathrm{E}+04$ & $2.11 \mathrm{E}+04$ \\
\hline & $\begin{array}{l}\text { Carbon } \\
\text { monoxide, } \\
\text { fossil }\end{array}$ & g & $3.12 \mathrm{E}+05$ & $5.05 \mathrm{E}+04$ & $3.63 \mathrm{E}+05$ \\
\hline \multirow[t]{5}{*}{ Acidification } & Sulfur dioxide & $\mathrm{g}$ & $8.51 \mathrm{E}+01$ & $4.83 \mathrm{E}+03$ & $4.92 \mathrm{E}+03$ \\
\hline & $\begin{array}{l}\text { Sulfuric acid, } \\
\text { dimethyl ester }\end{array}$ & $\mathrm{g}$ & 8.83E-10 & $0.00 \mathrm{E}+00$ & $8.83 \mathrm{E}-10$ \\
\hline & Sulfur oxides & g & $3.22 \mathrm{E}+04$ & $9.33 \mathrm{E}+03$ & $4.16 \mathrm{E}+04$ \\
\hline & Ammonia & g & $2.23 \mathrm{E}+02$ & $2.53 \mathrm{E}+02$ & $4.75 \mathrm{E}+02$ \\
\hline & $\begin{array}{l}\text { Ammonium } \\
\text { chloride }\end{array}$ & g & $7.38 \mathrm{E}-02$ & $8.60 \mathrm{E}-02$ & $1.60 \mathrm{E}-01$ \\
\hline \multirow{5}{*}{$\begin{array}{l}\text { Resource } \\
\text { consumption }\end{array}$} & Cobalt & g & $3.12 \mathrm{E}-03$ & $8.14 \mathrm{E}-02$ & $8.45 \mathrm{E}-02$ \\
\hline & Copper & g & $7.06 \mathrm{E}-04$ & $5.88 \mathrm{E}-04$ & $1.29 \mathrm{E}-03$ \\
\hline & Magnesium & g & $6.90 \mathrm{E}-03$ & $2.98 \mathrm{E}-01$ & 3.05E-01 \\
\hline & Manganese & g & $2.55 \mathrm{E}-03$ & $5.42 \mathrm{E}-02$ & $5.68 \mathrm{E}-02$ \\
\hline & Zinc & $\mathrm{g}$ & $4.70 \mathrm{E}-04$ & $3.92 \mathrm{E}-04$ & $8.63 \mathrm{E}-04$ \\
\hline
\end{tabular}




\subsubsection{Life cycle impact assessment (LCIA)}

LCIA is the process which identify the environmental impacts such the global warming potential, acidification potential, eutrophication potential, Ozone layer depletion, emissions to (air, land, and water), resource and energy consumption. The entire building life cycle steps for the case study building are shown in Fig. 6 .

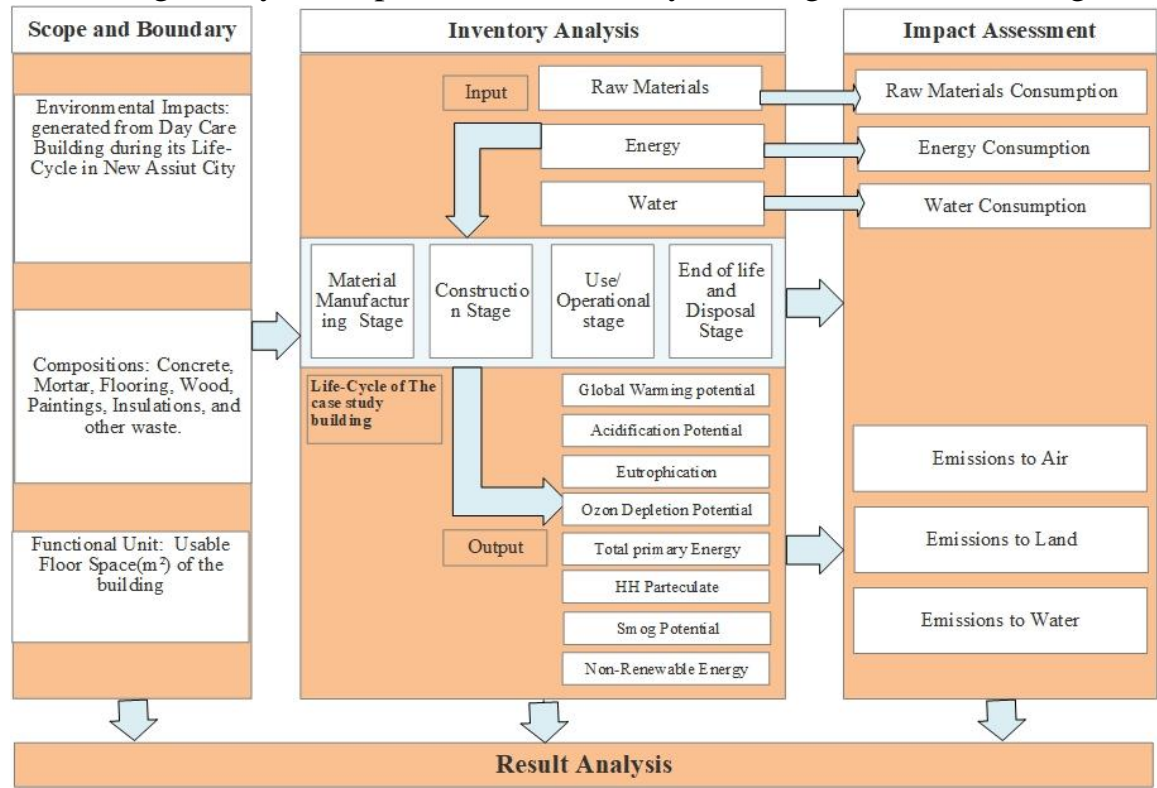

Fig. 6. The life cycle Impact Assessment for Day Care Project in Egypt.

\section{Results, Interpretation and discussion}

Fig. 7 indicates the total environmental impacts during the BLC. It shows that the most impactful stage is the material manufacturing stage, the highest environmental impact for this stage is the Ozone depletion potential with $\left(8.87 \times 10^{-3}\right) \mathrm{Kg}$ CFC-11eq. The second impactful stage is the use/maintenance stage; the highest environmental impact for this stage is the Human Health particulate with $\left(9.84 \times 10^{2}\right) \mathrm{kg}$ PM2.5eq.

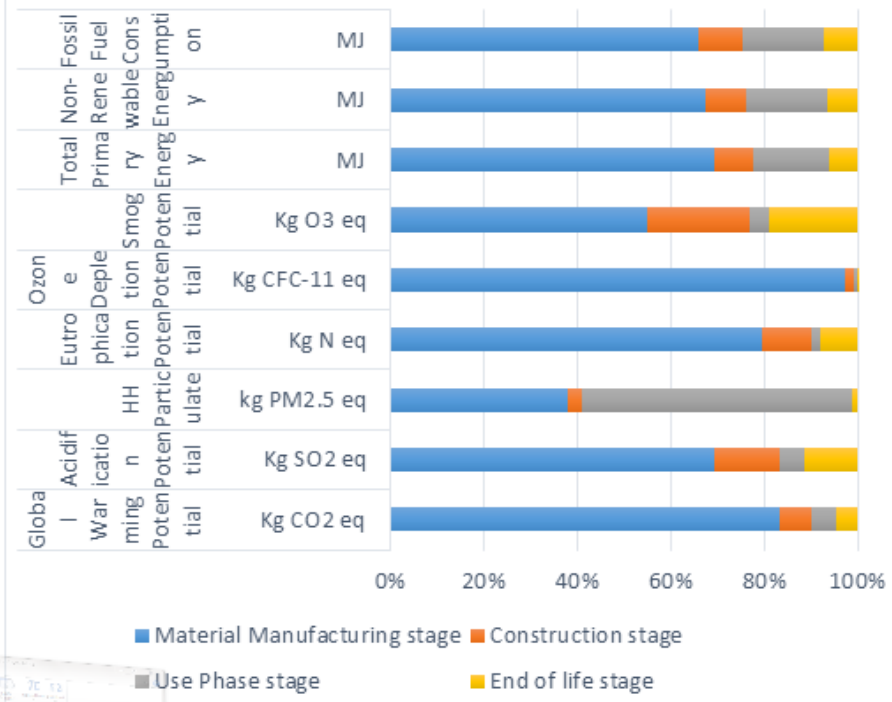

Fig. 7. The Environmental Impacts during BLC 
The environmental impacts are Global warming potential $\mathrm{Kg} \mathrm{CO}_{2} \mathrm{eq}$, Acidification Potential $\mathrm{Kg} \mathrm{SO}_{2}$ eq, Human Health Particulate Kg PM2.5eq, Eutrophication (air \& water) Kg Neq, Ozone Depletion Kg CFC-11eq, Smog (air) Potential $\mathrm{Kg} \mathrm{O}_{3}$ eq, Total Primary Energy MJ, NonRenewable Energy MJ, and Fossil Fuel Consumption MJ. Table 6 shows the total environmental impacts for every stage in the BLC. The highest negative effect for the whole BLC is the total primary energy as measured in this case study $\left(1.20 \times 10^{7}\right) \mathrm{MJ} / \mathrm{m}^{2},[11]$ confirmed this result and mentioned that the total primary energy for a prefabricated building module in Italy is 29.2 $\mathrm{GJ} / \mathrm{m}^{2}$. While, the non-renewable energy is $\left(1.12 \times 10^{7}\right) \mathrm{MJ} / \mathrm{m}^{2}$, and fossil fuel energy is $\left(1.01 \times 10^{7}\right) \mathrm{MJ} / \mathrm{m}^{2}$, then the global warming potential measured as $\left(1.02 \times 10^{6}\right) \mathrm{Kg} \mathrm{CO}_{2} \mathrm{eq}$.

Table 6.

Total environmental impacts for building materials during BLC

\begin{tabular}{|c|c|c|c|c|c|c|c|}
\hline $\begin{array}{c}\text { Environmental } \\
\text { Impacts }\end{array}$ & Unit & $\begin{array}{c}\text { Material } \\
\text { Manufacturing } \\
\text { stage }\end{array}$ & $\begin{array}{c}\text { Construction } \\
\text { stage }\end{array}$ & $\begin{array}{l}\text { Use } \\
\text { Phase } \\
\text { stage }\end{array}$ & $\begin{array}{c}\text { End of } \\
\text { life stage }\end{array}$ & $\begin{array}{c}\text { Disposal } \\
\text { stage }\end{array}$ & $\begin{array}{c}\text { Total } \\
\text { Effects }\end{array}$ \\
\hline $\begin{array}{l}\text { Global } \\
\text { Warming } \\
\text { Potential }\end{array}$ & $\begin{array}{c}\mathrm{Kg} \\
\mathrm{CO}_{2} \text { eq }\end{array}$ & $8.61 \times 10^{5}$ & $7.28 \times 10^{4}$ & $5.27 \times 10^{4}$ & $4.91 \times 10^{4}$ & $-1.90 \times 10^{4}$ & $1.02 \times 10^{6}$ \\
\hline $\begin{array}{l}\text { Acidification } \\
\text { Potential }\end{array}$ & $\begin{array}{c}\mathrm{Kg} \\
\mathrm{SO}_{2} \text { eq }\end{array}$ & $3.79 \times 10^{3}$ & $7.57 \times 10^{2}$ & $2.89 \times 10^{2}$ & $6.31 \times 10^{2}$ & $-8.63 \times 10^{-1}$ & $5.47 \times 10^{3}$ \\
\hline $\begin{array}{l}\text { HH } \\
\text { Particulate }\end{array}$ & $\begin{array}{c}\mathrm{kg} \\
\mathrm{PM} 2.5 \\
\text { eq }\end{array}$ & $6.44 \times 10^{2}$ & 47.8 & $9.84 \times 10^{2}$ & 20.1 & $-3.79 \times 10^{-1}$ & $1.70 \times 10^{3}$ \\
\hline $\begin{array}{l}\text { Eutrophication } \\
\text { Potential }\end{array}$ & $\begin{array}{l}\mathrm{Kg} \\
\mathrm{Neq}\end{array}$ & $3.88 \times 10^{2}$ & 51 & 9.74 & 39.4 & $-4.44 \times 10^{-2}$ & $4.88 \times 10^{2}$ \\
\hline $\begin{array}{l}\text { Ozone } \\
\text { Depletion } \\
\text { Potential }\end{array}$ & $\begin{array}{l}\mathrm{Kg} \\
\mathrm{CFC}- \\
11 \text { eq }\end{array}$ & $8.87 \times 10^{-3}$ & $1.72 \times 10^{-4}$ & $9.44 \times 10^{-5}$ & $2.01 \times 10^{-6}$ & 0 & $9.14 \times 10^{-3}$ \\
\hline Smog Potential & $\begin{array}{c}\mathrm{Kg} \\
\mathrm{O}_{3} \mathrm{eq}\end{array}$ & $5.98 \times 10^{4}$ & $2.36 \times 10^{4}$ & $4.60 \times 10^{3}$ & $2.07 \times 10^{4}$ & -8.73 & $1.09 \times 10^{5}$ \\
\hline $\begin{array}{l}\text { Total Primary } \\
\text { Energy }\end{array}$ & MJ & $8.33 \times 10^{6}$ & $9.87 \times 10^{5}$ & $1.98 \times 10^{6}$ & $7.27 \times 10^{5}$ & $-1.73 \times 10^{3}$ & $1.20 \times 10^{7}$ \\
\hline $\begin{array}{l}\text { Non- } \\
\text { Renewable } \\
\text { Energy }\end{array}$ & MJ & $7.56 \times 10^{6}$ & $9.76 \times 10^{5}$ & $1.94 \times 10^{6}$ & $7.26 \times 10^{5}$ & $-1.73 \times 10^{3}$ & $1.12 \times 10^{7}$ \\
\hline $\begin{array}{c}\text { Fossil Fuel } \\
\text { Consumption }\end{array}$ & MJ & $6.68 \times 10^{6}$ & $9.63 \times 10^{5}$ & $1.76 \times 10^{6}$ & $7.25 \times 10^{5}$ & $-3.47 \times 10^{3}$ & $1.01 \times 10^{7}$ \\
\hline
\end{tabular}

According to the previous results, and as shown in Table 7 this study confirm that the materials production stage alone accounted for more than $70 \%$ of the total environmental impacts caused by a building, [11] supported this result. The second influential stage is the use stage which contributes by $15 \%$ of the total impacts, then the construction stage contributes by $10 \%$. Finally, the disposal stage contributes by $-10 \%$, and that shows the importance of the waste treatment that the authors consumed for the case study building in Egypt. However, from other available literature review [6], [12] the most influential stage in the environment is the operational use stage it contributes more than $70-80 \%$.

Table 7.

Total Environmental Impacts percentage during BLC

\begin{tabular}{|l|l|l|}
\hline BLC stages & Total Environmental Impacts & Percentage \\
\hline Material Manufacturing Stage & $2.35 \mathrm{E}+07$ & $70 \%$ \\
\hline Construction Stage & $3.02 \mathrm{E}+06$ & $10 \%$ \\
\hline Use Stage & $5.73 \mathrm{E}+06$ & $15 \%$ \\
\hline End of life Stage & $2.25 \mathrm{E}+06$ & $5 \%$ \\
\hline Disposal stage & $-2.59 \mathrm{E}+04$ & $-10 \%$ \\
\hline
\end{tabular}


Fig. 8 shows the building life cycle emissions to air, land and water. The Material manufacturing stage release the biggest emissions to water, air, and land. Then the end of life stage releases the most emissions to land it releases about $60 \%$ of the total land emissions.

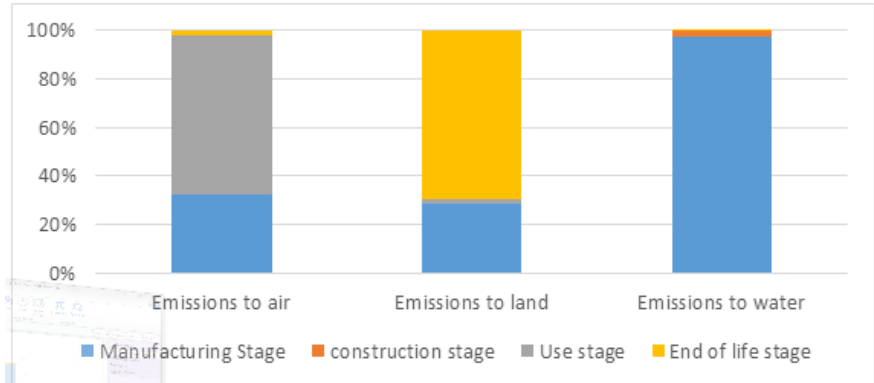

Fig. 8. Building material emissions during BLC

\section{Conclusion}

This paper measures the environmental impacts for a day care building in Egypt as a case study during its life cycle from the material manufacturing stage to the disposal stage with focusing on the end of life stage to help the construction industry stakeholders, engineers, and policy makers to reconsider the CDW management practice in Egypt. The results show that the material manufacturing stage is the most impactful stage which contributes $70 \%$, which consumes raw materials, energy and fossil fuel energy. Then the use/maintenance stage is the second impactful stage. However, the end of life stage contributes by $-10 \%$ of the total environmental impacts. As for the emissions to air, land and water; the material manufacturing stage is the main contributor to the water emissions. The use/maintenance stage is the main contributor to the air emissions. Moreover, the end of life stage has the role in the emissions to land; this stage produces the construction and demolition waste.

The findings of the research pointed out the relevance of LCA in the assessment of the building environmental performances. The aforementioned results indicate the opportunities to reduce the environmental impacts during BLC by using sustainable building materials in Egypt, using recycled building materials instead of building with new materials. Motivate applying 3Rs principle (Reduce, Reuse \& Recycling) during BLC. Fees impose on contractors for illegal waste dumping.

\section{REFERENCES}

[1] J. W. H. T. V. W. \&. Z. J. Wang, " Considering life-cycle environmental impacts and society's willingness for optimizing construction and demolition waste management fee: An empirical study of China.," Journal of Cleaner Production, 206, pp. 1004-1014., 2019.

[2] www.athenasmi.org, "Life cycle assessment (LCA) is a scientific method for measuring the environmental footprint of materials, products and services over their entire lifetime.," Athena Sustainable Materials Institue , Canada, 2012.

[3] A. E. J. \&. V. A. K. Di Maria, "Downcycling versus recycling of construction and demolition waste: Combining LCA and LCC to support sustainable policy making.," Waste Management, 75, pp. 3-21, 2018.

[4] M. O. J. L. T. P. E. M. Mark Goedkoop, "Introduction to LCA with SimaPro," www.presustainability.com, USA, 2016.

[5] K. W. M. A. \&. P. R. Chomkhamsri, International reference life cycle data system (ILCD) handbook: review schemes for life cycle assessment. In Towards life cycle sustainability 
management, Springer, Dordrecht., 2011.

[6] A. A. M. M. N. A. M. B. M. F. \&. I. M. G. Ali, "Environmental life cycle assessment of a residential building in Egypt: a Case Study.," Procedia Technology, 19, , pp. 349-356., 2015.

[7] M. S. Abdelhamid, "Assessment of different construction and demolition waste management approaches," HBRC Journal, 10(3), pp. 317-326, 2014.

[8] H. Yuan, "A SWOT analysis of successful construction waste management.," Journal of Cleaner Production, 39,, pp. 1-8., 2013.

[9] D. \&. K. M. A. Altuncu, "Management and recycling of constructional solid waste in Turkey.," Procedia Engineering, 21,, pp. 1072-1077., 2011.

[10] "Green design codes and standards now have LCA paths - finally, a performance basis is coming to sustainable design.," 29 January 2019. [Online]. Available: http://www.athenasmi.org/resources/about-lca/lca-in-construction-practice/.

[11] G. G. F. L. S. F. M. C. M. \&. A. V. Tumminia, "Life cycle energy performances and environmental impacts of a prefabricated building module," Renewable and Sustainable Energy Reviews, 92, , pp. 272-283., 2018.

[12] P. P. K. A. T. E. A. \&. G. J. P. Evangelista, "Environmental performance analysis of residential buildings in Brazil using life cycle assessment (LCA).," Construction and Building Materials, 169, , pp. 748-761, 2018.

[13] H. Yuan, "Key indicators for assessing the effectiveness of waste management in construction projects.," 2013, pp. 476-484, Ecological Indicators, 24.

[14] A. A. M. N. A. B. M. \&. G. M. Ali, "Towards An Integrated Tool To Estimate Carbon Emissions From Life Cycle Assessment Of Building Materials In Egypt," IMPACT: IJRET, 2(3),, pp. 81-92., 2014. 


\section{التحليل البيئى لمبنى حضانة بمصر من خلال أداة تقييم دورة حياة المبنى}

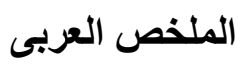

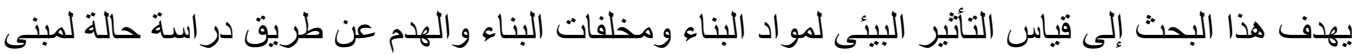

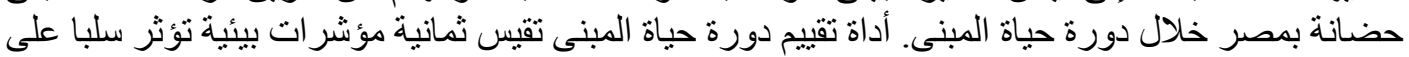

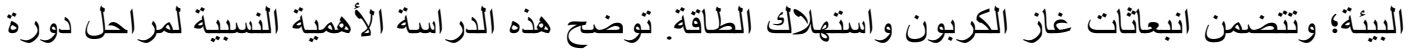

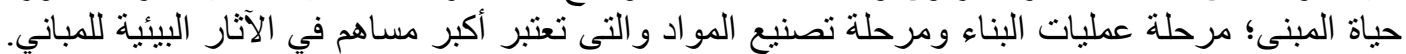

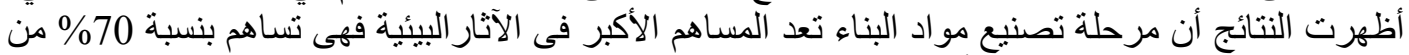

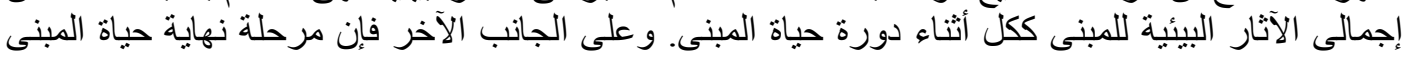

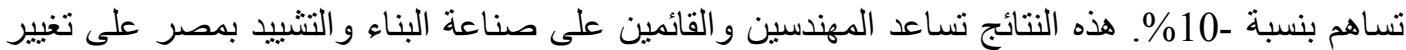
ممارساتهم تجاه عملية إدارة مخلفات البناء و الهدم. 